\title{
ANALISIS KEBIJAKAN PENGENAAN PAJAK ATAS BAHAN BAKAR MINYAK BERSUBSIDI MINYAK SOLAR
}

Andi M. Iqbal ${ }^{1}$, Roy V. Salomo ${ }^{2}$

Departemen Ilmu Administrasi, Fakultas Ilmu Sosial dan Ilmu Politik, Universitas Indonesia

Email:amiqbal78@gmail.com

Keywords: Value Added Tax (VAT); Vehicle Fuel Tax; Fuel; Subsidy
The purpose of this research is to analyze the tax policy on subsidized fuel of diesel oil in Indonesia. Currently, subsidized fuel in Indonesia are taxed Value Added Tax (VAT) by central government and Vehicle Fuel Tax by local government. This research is using post positivist approach with qualitative method of research.

The results of this research conclude tax on subsidized fuel oil are taken by goverment with the purpose of revenue productivity for both central governement and local government. Besides, to control the consumption of subsidized fuel in the public. By taxing 2 kind of taxes on subsidized fuel diesel oil incurring the double taxation and resulting those taxes are not neutral for economic since the subsidized fuel are the vital public needs.

Government should evaluate the tax policy on subsidized fuel diesel oil by exempting the VAT on subsidized fuel in order to maintain the economic stability and make a strict policy on controlling the consumption on subsidized fuel diesel oil only for them who reserve to get the subsidy.

\section{PENDAHULUAN}

Subsidi energi terutama Bahan Bakar Minyak (BBM) terus meningkat dari tahun ketahun menjadi satu bagian yang cukup signifikan dalam APBN disisi pengeluaran/belanja negara. Berdasarkan data dari Kementrian Keuangan Republik Indonesia, belanja subsidi Bahan bakar terus meningkat dimana pada tahun 2013, 2014 dan 2015 secara berurutan belanja subsidi BBM adalah Rp. 199,9 Triliun, Rp. 210,7 Triliun dan Rp. 276 Triliun. Belanja subsidi BBM yang terus meningkat dipengaruhi oleh beberapa faktor. Harga BBM kita dipengaruhi oleh nilai minyak mentah dunia yang cukup fluktuatif dan juga nilai tukar Rupiah dibandingkan Dollar Amerika Serikat, dimana BBM terutama BBM subsidi kita beli dengan mengimpor berdasarkan harga pasar internasional berbasis Dollar Amerika Serikat. Dikarenakan BBM subsidi di Indonesia masih didominasi produk impor, maka belanja subsidi BBM akan terus tidak stabil dan naik turun berdasarkan harga minyak mentah dunia dan fluktuasi nilai tukar Dollar Amerika Serikat. Selain itu, peningkatan konsumsi BBM bersubsidi dimasyarakat yang terus meningkat mempengaruhi peningkatan subsidi BBM dalam APBN. Pada tahun 2013 konsumsi BBM nasional sebesar 1,4 juta barel per hari (bph). Ini dipasok dari pengilangan minyak mentah produksi dalam negeri rata-rata $650.000 \mathrm{bph}$, hasil pengilangan minyak mentah impor rata-rata 350.000 bph dan impor BBM sekitar 400.000 bph. Kebutuhan BBM meningkat rata-rata 120.000 bph per tahun (Priyanto \& Ginting, 2014).

Pemerintah dihadapkan pada tantangan yang besar sebagai akibat meningkatnya fluktuasi harga minyak. Mengingat cukup rentan perubahan belanja subsidi BBM dalam APBN, perlu dipikirkan bagaimana kebijakan subsidi BBM dapat lebih stabil dan tidak menjadi beban yang tidak terkontrol dimasa yang akan datang. Hal ini dikarenakan faktor penyebab fluktuasi harga minyak dunia dan nilai tukar Rupiah merupakan hal-hal yang berada diluar kendali Pemerintah. Perubahan harga BBM bersubsidi merupakan suatu kebijakan yang umum dilakukan oleh Pemerintah dalam rangka mengontrol beban belanja subsidi dalam APBN.

Dalam APBN 2015, arah kebijakan subsidi BBM diupayakan sebagai berikut:

1. Efisiensi anggaran subsidi BBM;

2. Konversi BBM ke BBG (Bahan Bakar Gas);

3. Pengendalian konsumsi BBM bersubsidi;

4. Pengembangan energi baru dan terbarukan (EBT); 
5. Pengurangan konsumsi BBM bersubsidi secara bertahap.

Kebijakan efisiensi anggaran subsidi BBM akan otomatis berdampak pada harga BBM bersubsidi yang sangat mempengaruhi perekonomian masyarakat Indonesia, sehingga setiap ada perubahan kenaikan harga dapat dipastikan terjadi mempengaruhi kenaikan harga-harga kebutuhan masyarakat. Hal ini dikarenakan BBM bersubsidi mempengaruhi biaya transportasi yang cukup signifikan dalam produk-produk kebutuhan masyarakat. Selain aspek ekonomi, setiap kenaikan BBM bersubsidi memiliki dampak sosial politik dimasyarakat. Penolakan dari masyarakat hingga demonstrasi masyarakat dan mahasiswa diberbagai kota serta tentangan dari parlemen (DPR) terkait kebijakan Pemerintah menaikkan harga BBM bersubsidi.

Dilihat dari aspek ekonomi, setiap kenaikan harga BBM akan berdampak pada perekonomian secara menyeluruh. Kenaikan harga BBM tentu akan menimbulkan dampak inflasi, dimana inflasi yang timbul akan menurunkan daya beli dan penurunan daya beli akan mengakibatkan bertambahnya jumlah orang miskin. Memang secara nyata, menaikkan harga BBM bersubsidi dapat meringankan beban APBN negara dengan berkurangnya beban subsidi BBM, akan tetapi faktor lain dari dampak kenaikan BBM akan berdampak kepada kenaikan harga-harga dan daya beli masyarakat terutama masyarakat yang memang berhak untuk mendapatkan subsidi dari Pemerintah. Secara hitunghitungan, Prasetiantono di harian Kompas (Jumat, 29 Agustus 2014, halaman 1) memaparkan jika kenaikan harga BBM naik Rp. 500 per liter akan menciptakan ruang fiskal sebesar Rp 24 triliun namun berakibat tambahan inflasi tahunan 0,6\%. Jika harga BBM dinaikkan Rp. 1,000 per liter akan menciptakan tambahan fiskal Rp. 48 triliun dengan tambahan inflasi tahunan sebesar 1,2\%. Sedangkan menurut M. Chatib Basri (Kompas, Rabu 23 Juli 2014, halaman 17), setiap kenaikan BBM bersubsidi sekitar 10\%, inflasi akan naik sekitar $1 \%$.

Dari pemaparan aspek ekonomi diatas, permasalahan sosial yang akan timbul berikutnya adalah permasalahan kemampuan daya beli masyarakat yang berimbas pada meningkatnya jumlah orang miskin. Hal ini perlu dipikirkan sebagai suatu permasalahan bagi Pemerintah ketika akan menaikkan harga BBM bersubsidi. Ketika Pemerintahan Susilo Bambang Yudhoyono, kompensasi dana tunai sebagai program kepada masyarakat miskin akibat kenaikan BBM bersubsidi diberikan melalui Bantuan Langsung Sementara Masyarakat (BLSM) kepada masyarakat miskin. Sedangkan Pemerintahan Joko Widodo menyalurkan dana kompensasi kenaikan BBM bersubdisi melalui penyaluran program Kartu Keluarga Sejahtera, Kartu Indonesia Sehat dan Kartu Indonesia Pintar.

Pemerintahan Joko Widodo memang melakukan beberapa perubahan dalam peraturan menetapkan harga BBM bersubsidi melalui Peraturan Presiden Republik Indonesia Nomor 191 tahun 2014 tentang Penyediaan, Pendistribusian dan Harga Jual Eceran Bahan Bakar Minyak serta dalam Peraturan Menteri Energi dan Sumber Daya Mineral No. 39 tahun 2014 tentang Perhitungan Harga Jual Eceran Bahan Bakar Minyak dan perubahannya dalam Peraturan Menteri Energi dan Sumber Daya Mineral No. 04 tahun 2015, ada beberapa hal yang menjadi catatan dalam menentukan harga BBM bersubsidi, antara lain:

1. Terdapat tiga kategori jenis BBM yang harga jual ecerannya diatur oleh Pemerintah, yaitu: BBM Tertentu, BBM Khusus Penugasan dan BBM Umum.

2. BBM Tertentu adalah BBM yang masih diberikan subsidi terdiri atas Minyak Tanah dan Minyak Solar. Khusus minyak solar diberikan subsidi paling banyak Rp. 1,000 per liternya.

3. BBM Khusus Penugasan adalah BBM yang didistribusikan diwilayah penugasan dengan biaya distribusi $2 \%$ dari harga dasar ditambah Pajak Pertambahan Nilai (PPN) dan Pajak Bahan Bakar Kendaraan Bermotor (PBBKB). BBM Khusus Penugasan adalah Bensin (gasoline) Premium RON 88.

4. Wilayah penugasan untuk BBM Khusus Penugasan adalah seluruh Wilayah Negara Kesatuan Republik Indonesia kecuali wilayah Provinsi DKI Jakarta, Provinsi Jawa Barat, Provinsi Jawa Tengah, Provinsi Jawa Timur, Provinsi Daerah Istimewa Yogyakarta dan Propinsi Bali.

5. BBM Umum adalah BBM diluar BBM Tertentu dan BBM Khusus Penugasan, akan tetapi Pemerintah menetapkan margin keuntungan Badan Usaha yang menyalurkan BBM Umum antara $5-10 \%$.

6. Harga Jual Eceran BBM merupakan harga dasar (biaya perolehan, biaya distribusi, dan biaya penyimpanan termasuk margin) ditambah PPN dan PBBKB.

7. Menteri berhak menetapkan harga jual eceran lebih dari 1 kali setiap bulannya. 
Saat ini, Pemerintah menetapkan harga eceran BBM bersubsidi secara fluktuatif setiap bulan, mengikuti perkembangan harga minyak mentah dunia. Walaupun kebijakan subsidi BBM terutama dalam penetapan harga telah dilakukan perubahan, Pemerintah saat ini tetap memilih kebijakan untuk mengenakan pajak yaitu PPN 10\% dan PBBKB 5\% atas produk BBM bersubsidi. Dengan arti lain, atas konsumsi BBM bersubsidi, masyarakat tidak saja memperoleh subsidi dari konsumsi tersebut, akan tetapi sekaligus menyumbang penerimaan bagi Negara dan Daerah melalui pembayaran PPN dan PBBKB. Beban subsidi BBM menjadi beban pengeluaran Pemerintah memang terlihat cukup besar disisi pengeluaran APBN. Akan tetapi, disisi penerimaan pajak terutama PPN terdapat penerimaan PPN atas BBM bersubsidi. Selain itu, disisi penerimaan Pemerintah Daerah seluruh Indonesia, terdapat penerimaan pajak atas BBM bersubsidi yaitu, PBBKB. Pemerintah hingga saat ini, belum menjadikan kebijakan fiskal terutama kebijakan perpajakan yaitu PPN dan PBBKB sebagai instrumen dalam menentukan kenaikan atau penurunan harga jual eceran BBM bersubsidi.

Menurut Mansury (1999: 3), dari dua fungsi pajak budgetair dan regulerend, keduanya merupakan satu kesatuan yang saling melengkapi dan tidak dapat dipisahkan satu sama lain. Misalnya, walaupun pajak berfungsi sebagai sumber pendapatan negara dari masyarakat, tetapi harus pula dipertimbangkan berbagai dampaknya pada masyarakat, baik berupa dampak sosial, ekonomi, budaya ataupun dampak lainnya. Sebaliknya, apabila fungsi mengatur dari pajak akan digunakan sebagai tujuan, maka perlu diperhatikan pengaruhnya terhadap penerimaan negara disamping perlu dilakukan analisis terhadap efektivitas penggunaan pajak untuk mencapai sasaran lain keperluan pembiayaan negara.

Pemerintah dapat menjadikan kebijakan pajak sebagai salah satu alat dalam kebijakan BBM bersubsidi, terutama dalam hal menentukan harga jual eceran dimasyarakat. Secara nyata, dengan menerapkan PPN 10\% dan PBBKB 5\% dalam harga jual eceran BBM bersubsidi, nilai jualnya menjadi lebih mahal dimasyarakat. Bila penggunaan BBM bersubsidi dimasyarakat akan diperketat hanya bagi golongan masyarakat bawah yang memang berhak untuk mendapatkan subsidi, maka kebijakan penerapan PPN dan PBBKB dalam BBM bersubsidi dapat dikaji kembali. Hal yang sama sudah dilakukan Pemerintah terhadap barang subsidi lainnya, yaitu Gas Elpiji tabung 3 KG. Sejak dilakukan konversi penggunaan minyak tanah ke gas elpiji, Pemerintah menerapkan kebijakan untuk menanggung PPN terhutang atas Gas Elpiji 3 KG sesuai diatur dalam Peraturan Menteri Keuangan No. 88/PMK.011/2011.

\section{TINJAUAN TEORITIS}

Dunn (2000: 109), mendefinisikan kebijakan publik sebagai suatu rangkaian pilihan-pilihan yang kurang lebih saling berhubungan (termasuk keputusan-keputusan untuk tidak bertindak) yang dibuat oleh badan dan pejabat pemerintah, diformulasikan dalam bidang-bidang isu seperti pertahanan, energi, kesehatan, pendidikan, dan kesejahteraan masyarakat. Menurutnya, kebijakan publik merupakan bagian dari suatu sistem kebijakan (policy system), yang merupakan suatu pola institusional yang mencakup hubungan timbal-balik antara tiga unsur, yakni kebijakan publik, pelaku kebijakan dan lingkungan kebijakan.

Dalam membuat suatu kebijakan, Anderson (2011: 108) berpendapat diperlukan beberapa pemikiran atau pertanyaan yang harus tetap dipikirkan dalam membuat suatu kebijakan yang berhasil:

1. Apakah secara teknik kebijakan yang akan dihasilkan menarik sebagai suatu bentuk penyelesaian masalah?

2. Apakah secara biaya (budget), suatu kebijakan yang akan dibuat dapat diterima?

3. Apakah secara politik, suatu kebijakan akan mendapat dukungan?

4. Apakah suatu kebijakan dapat diterima publik/masyarakat apabila sudah dihasilkan?

Pertanyaan diatas terkait dengan keberhasilan suatu kebijakan dapat dihasilkan. Perlu diperhatikan dukungan politik, biaya yang akan dikeluarkan dalam menghasilkan suatu kebijakan serta dukungan publik dalam pelaksanaannya. Hal tersebut diperlukan agar suatu kebijakan tidak menjadi beban dalam pelaksanaannya serta dapat ditaati atau dijalankan oleh semua pihak.

Menurut Dunn (1991) sebagaimana dikutip oleh Suharto (2005: 85), ada tiga bentuk atau model analisis kebijakan yaitu model prospektif, model retrospektif dan model integratif dengan penjelasan sebagai berikut: 
1. Model Prospektif adalah bentuk analisis kebijakan yang mengarahkan kajiannya pada konsekuensi-konsekuensi kebijakan sebelum suatu kebijakan diterapkan. Model ini dapat disebut sebagai model prediktif karena seringkali melibatkan teknik-teknik peramalan (forecasting) untuk memprediksi kemungkinan-kemungkinan yang akan timbul dari suatu kebijakan yang akan diusulkan.

2. Model Retrospektif adalah analisis kebijakan yang dilakukan terhadap akibat-akibat kebijakan setelah suatu kebijakan diimplementasikan. Model ini biasanya disebut sebagai model evaluatif, karena banyak melibatkan pendekatan evaluasi terhadap dampak-dampak kebijakan yang sedang atau telah diterapkan.

3. Model integratif adalah model perpaduan antara kedua model diatas. Model ini kerap disebut sebagai model komprehensif atau model holisitk, karena analisis dilakukan terhadap konsekuensikonsekuensi kebijakan yang mungkin timbul, baik sebelum maupun sesudah suatu kebijakan diimplementasikan. Model analisis kebijakan biasanya melibatkan teknik-teknik peramalan dan evaluasi secara integrasi.

Dalam melakukan analisis kebijakan pengenaan pajak atas BBM bersubsidi Minyak Solar, diperlukan analisis kebijakan dengan model integratif dimana diperlukan analisis serta evaluasi terhadap kebijakan yang saat ini sudah diterapkan dan juga peramalan atas konsekuensi serta dampak bagi masyarakat serta keuangan negara apabila kebijakan tersebut diubah atau direvisi oleh Pemerintah.

Vito Tanzi (1990) yang dikutip Mansury (1999: 19) membagi fungsi kebijakan fiskal menjadi:

1. Allokasi;

2. Distribusi;

3. Stabilisasi;

4. Pertumbuhan.

Tanzi mempertimbangkan perbedaan situasi dan kondisi dalam menerapkan kebijakan fiskal di negara-negara maju dan negara-negara yang sedang berkembang. Terdapat keterbatasan dalam menerapkan kebijakan fiskal dinegara-negara berkembang dan tidak serta merta setiap kebijakan fiskal yang berhasil diterapkan dinegara maju akan berhasil apabila diimplementasikan dinegara-negara berkembang. Untuk itu Tanzi menyarankan beberapa hal dalam menyusun kebijakan fiskal dinegaranegara yang sedang berkembang:

1. Apabila ada alternatif-alternatif untuk dipilih, disarankan kebijakan fiskal yang dapat diterapkan dengan lebih mudah.

2. Hendaknya kebijakan yang memberikan terlalu banyak keleluasaan kepada "policy maker" atau kepada birokrat dihindari.

3. Hendaknya dibatasi banyak intervensi Pemerintah atas perekonomian. Ini tidak berarti makin kecil peranan Pemerintah, makin baik untuk perekonomian. Namun benar, bahwa sistem pajak yang lebih sederhana pelaksanaan pemungutannya adalah lebih baik.

4. Subsidi yang eksplisit adalah lebih baik daripada yang implisit.

5. Kebijakan fiskal yang lebih transparan adalah lebih baik daripada kebijakan yang tidak jelas sasarannya dan tidak jelas dasar pertimbangannya.

Perbedaan setiap negara dalam membuat suatu kebijakan fiskal mengharuskan Pemerintah memperhatikan aspek-aspek lain seperti aspek sosial dan aspek politik, walaupun kebijakan fiskal sendiri merupakan kebijakan untuk mempengaruhi perekonomian. Kebijakan fiskal perlu juga mengakomodasi semua kepentingan yang ada dalam masyarakat. Ichimura (1989) dikutip oleh Mansury (1999: 74) berpendapat bahwa ekonomi politik dari kebijakan fiskal dapat dipelajari sebagai tiga tahap pembuatan kebijakan sebagai berikut:

1. Analisis keadaan perekonomian dan resep yang harus dipakai dalam kebijakan yang berkenaan. Ini merupakan pendekatan standar dalam buku-buku teks ilmu ekonomi, sehingga tidak memerlukan penjelasan lebih lanjut. Namun demikian, beberapa masalah tidak dibahas dalam buku-buku teks, padahal penting dalam praktek ekonomi politik kebijakan fiskal.

2. Proses pembuatan keputusan: kebijakan-kebijakan yang dipilih dalam rangka lembaga-lembaga tertentu dan modus operandinya, sedang "vested interest" dan pendapat-pendapat berbagai "pressure group" ikut diperhatikan. 
3. Pelaksanaan kebijakan: bagaimana kebijakan-kebijakan yang dianut dilaksanakan secara efektif bergantung kepada tanggapan dari lembaga swasta dan lembaga publik serta perseorangan atas kebijakan-kebijakan yang bersangkutan dan lembaga-lembaga yang melaksanakan kebijakankebijakan tersebut.

Stiglitz (1999: 457) berpendapat apabila Pemerintah dalam memutuskan untuk meningkatkan penerimaan pajak, harus memperhatikan beberapa hal yang disebut sebagai suatu sistem pajak yang baik:

1. Economics efficiency: sistem pajak tidak akan mendistorsi efisiensi alokasi dari sumber daya.

2. Adminstrative simplicity: sistem pajak seharusnya mudah untuk dilaksanakan dan tidak mahal pelaksanaannya.

3. Flexibility: sistem pajak harus dapat merespon setiap perubahan ekonomi.

4. Political responsibility: sistem pajak harus dibuat yang meyakinkan masyarakat tentang pembayaran pajaknya serta transparan dalam pelaksanaannya.

5. Fairness: sistem pajak harus adil perlakuannya bagi setiap masyarakat.

OECD (2014) mendeskripsikan Neutrality: Taxation should seek to be neutral and equitable between forms of business activities. Pajak yang netral dapat memberikan kontribusi terhadap efisiensi dengan memastikan alokasi yang optimal dalam tujuan produksi. Distorsi dan timbulnya deadweight loss akan terjadi ketika perubahan harga menyebabkan perbedaan dalam supply dan demand dibandingkan ketika pajak tidak dikenakan. Netralitas pajak juga dapat menyebabkan suatu sistem perpajakan meningkat penerimaannya tanpa menimbulkan diskriminasi dalam pilihan aktivitas ekonomi tertentu.

\section{METODE PENELITIAN}

Pendekatan penelitian yang digunakan oleh peneliti dalam penulisan tesis ini adalah pendekatan post-positivist dengan metode penelitian kualitatif. Pendekatan post-positivist digunakan untuk mencapai sebuah pemahaman yang mendalam (insight) dan menyeluruh (whole) terhadap fenomena yang terjadi melalui proses wawancara mendalam dan observasi partisipasi dalam memahami makna fenomena yang ada tersebut serta makna simbolis dibalik realita yang ada. Penelitian ini menitik beratkan pada upaya untuk memberikan deskripsi umum secara sistematis, faktual dan akurat mengenai fakta-fakta, sifat-sifat fenomena yang diselidiki dari suatu objek penelitian serta dipaparkan dengan apa adanya. Dalam penelitian ini, pendekatan post-positivist digunakan untuk dapat melihat secara menyeluruh atau mendapatkan gambaran yang menyeluruh terkait kebijakan pemerintah untuk mengenakan pajak atas BBM bersubsidi khususnya Minyak Solar di Indonesia

Berdasarkan tujuannya, penelitian ini merupakan penelitian deskriptif. Sesuai dengan tujuannya, penelitian ini berusaha untuk mendapatkan gambaran pemahaman dibalik kebijakan Pemerintah terkait kebijakan pengenaan pajak atas BBM bersubsidi Minyak Solar. Berdasarkan manfaatnya, penelitian ini dilakukan secara murni oleh peneliti, yaitu keingintahuan peneliti terhadap hasil suatu aktifitas dan fenomena sosial tertentu. Penelitian selanjutnya diharapkan menjadi sumber metode, teori, dan gagasan bagi penelitian selanjutnya. penelitian ini termasuk penelitian murni karena ditujukan untuk kebutuhan peneliti sendiri sehingga peneliti bebas untuk menentukan permasalahan yang ingin diteliti. Berdasarkan dimensi waktu, penelitian ini menggunakan jenis cross sectional karena penelitian ini mengambil satu bagian dari gejala (populasi) pada waktu tertentu yaitu selama April hingga Juni 2015 dan tidak melakukan perbandingan dengan penelitian sebelumnya.

Adapun teknik pengumpulan data pada penelitian ini adalah:

\section{Studi Kepustakaan}

Teknik pengumpulan data yang juga digunakan dalam penelitian ini adalah studi kepustakaan. Studi ini dilakukan dengan membaca dan mengumpulkan data dan informasi dari Undang-Undang Perpajakan, peraturan-peraturan perpajakan, buku-buku, paper atau makalah, jurnal, majalah, surat kabar, bahan seminar, penelusuran di internet untuk mendapatkan data-data yang relevan dengan permasalahan penelitian.

\section{Studi Lapangan}

Dalam studi lapangan, teknik pengumpulan data yang digunakan adalah melalui wawancara. Wawancara dilakukan dengan informan dimana peneliti memiliki sejumlah pertanyaan dengan 
tujuan untuk mendapatkan keterangan mengenai permasalahan yang diangkat. Wawancara dilakukan untuk mendapatkan gambaran dari informan terkait permasalahan dalam penelitian ini dan dilakukan secara langsung face to face.

Dalam penelitian ini, peneliti melakukan wawancara mengenai kebijakan pengenaan pajak atas BBM bersubsidi Minyak Solar melalui beberapa key informan. Dalam penelitian ini dibutuhkan penentuan key informan yang tepat. Dalam penelitian ini, narasumber yang diwawancara adalah narasumber yang memahami kebijakan fiskal, kebijakan perpajakan serta memahami kebijakan harga BBM. Narasumber berasal dari institusi Pemerintahan sebagai perumus kebijakan, pengamat kebijakan, ahli atau pakar serta akademisi

Batasan dalam penelitian ini adalah penelitian ini hanya memfokuskan permasalahan kepada kebijakan Pemerintah terkait pengenaan pajak atas BBM bersubsidi Minyak Solar. Pajak yang dikenakan atas BBM adalah PPN dan PBBKB.

\section{HASIL PENELITIAN DAN PEMBAHASAN}

Harga BBM bersubsidi merupakan persoalan sensitif yang kerap memunculkan kontroversi, baik pro-kontra kenaikan maupun besaran kenaikannya. Kontroversi mengenai besaran kenaikan harga muncul karena informasi yang tidak lengkap mengenai bagaimana pemerintah menentukan harga patokan jenis-jenis BBM tertentu. Berkaitan dengan penurunan tajam harga minyak mentah di pasar dunia, apakah benar pemerintah saat ini masih memberikan subsidi dalam harga BBM. Lalu bila kedepan, harga minyak mentah dunia di pasar internasional mengalami kenaikan, apakah pemerintah akan mempertahankan kebijakan untuk tetap memberikan subsidi secara dipatok, seperti subsidi untuk minyak solar yang diberikan patokan maksimal Rp. 1.000,- per liternya sebagaimana diatur dalam Peraturan Presiden No.191/2014 jo. Permen ESDM 39/2014: Minyak Solar ditetapkan dengan formula sesuai dengan Harga Dasar ditambah Pajak Pertambahan Nilai (PPN) dan Pajak Bahan Bakar Kendaraan Bermotor (PBBKB), dan dikurangi subsidi paling banyak sebesar Rp 1.000 (seribu rupiah)

Formula perhitungan subsidi dalam BBM perlu juga dijadikan informasi kepada masyarakat luas. Walaupun tidak dipublikasikan secara terbuka, informasi mengenai formula perhitungan harga patokan dalam menentukan subsidi BBM tertentu sebenarnya dapat diketahui masyarakat. Untuk mengurangi kontroversi di masyarakat dan menjaga kredibilitas kebijakan pemerintah, perlu dibuat formula penentuan harga patokan yang lebih sederhana disertai penyediaan informasi lengkap berkaitan dengan harga patokan tersebut

Dengan formula yang lebih sederhana dan mudah dimengerti, penentuan besaran subsidi BBM diharapkan menjadi lebih akurat dan akuntabel. Selain itu, masyarakat dapat membandingkan harga keekonomian BBM, termasuk untuk BBM non-subsidi. Di tengah keterbukaan dan akses informasi yang semakin luas, masyarakat juga dapat membandingkan harga BBM tertentu di dalam negeri dan di luar negeri. Dengan terbukanya informasi terkait subsidi BBM, dapat membuat masyarakat lebih memahami tujuan subsidi BBM kepada yang selayaknya untuk mendapatkan subsidi.

Terkait formula perhitungan subsidi BBM, aspek politik dalam membuat kebijakan tersebut sangat kental terasa. Ada kesan yang ditutupi selama ini dalam perhitungan formula subsidi BBM, sehingga hanya dipahami pihak-pihak tertentu terkait pengambilan kebijakan. Pengungkapan secara jelas ke masyarakat luas mengenai formulasi perhitungan subsidi BBM belum dapat sepenuhnya dapat dipahami dan dimengerti secara gamblang. Bila concern pemerintah adalah APBN agar lebih stabil, maka terkait subsidi BBM, banyak hal yang harus dibenahi pemerintah sebagaimana rekomendasi Tim Reformasi Tata Kelola Minyak dan Gas Bumi, mulai permasalahan penyaluran agar tepat sasaran, pengadaan BBM impor hingga formulasi perhitungan subsidi untuk BBM.

Dari sisi peraturan perundang-undangan, Undang-Undang Nomor 22 tahun 2001 tentang Minyak dan Gas Bumi Pasal 8 ayat 2 menyatakan Pemerintah wajib menjamin ketersediaan dan kelancaran pendistribusian BBM yang merupakan komoditas vital dan menguasai hajat hidup orang banyak diseluruh wilayah NKRI. Bahkan dalam Undang-Undang Nomor 30 tahun 2007 tentang Energi Pasal 7 ayat 2 mengatur agar Pemerintah dan Pemerintah Daerah menyediakan dana subsidi untuk kelompok masyarakat tidak mampu. Sesuai peraturan diatas, kewajiban pemerintah terkait distribusi BBM keseluruh wilayah Indonesia serta memastikan masyarakat tidak mampu untuk tetap dapat mengkonsumsi BBM melalui program subsidi BBM telah diatur dan mengikat secara legal 
konstitusional. Bila pemerintah mengabaikan peraturan tersebut, sama saja pemerintah telah mengabaikan peraturan yang telah dibuat sebelumnya dan melanggar komitmen terhadap masyarakat.

Dalam perhitungan yang lebih sederhana, saat ini subsidi untuk minyak solar mengacu kepada Peraturan Presiden Nomor 191/2014 jo. Permen ESDM 39/2014: Minyak Solar ditetapkan dengan formula sesuai dengan Harga Dasar ditambah Pajak Pertambahan Nilai (PPN) dan Pajak Bahan Bakar Kendaraan Bermotor (PBBKB), dan dikurangi subsidi paling banyak sebesar Rp 1.000 (seribu rupiah). Perhitungan pajak-pajak dalam per liter minyak solar adalah sebagai berikut:

Tabel 1. Komponen Pajak-Pajak Minyak Solar

\begin{tabular}{lc}
\multicolumn{1}{c}{ Komponen Harga } & Rupiah \\
\hline Harga Jual Eceran per & 6.900 \\
31/05/2015 & 6.000 \\
Harga Dasar & 600 \\
PPN10\% & 300 \\
PBBKB 5\% & \\
\hline
\end{tabular}

Sumber: Diolah oleh penulis

Saat ini, dalam satu liter minyak solar, terdapat komponen PPN 10\% sebesar Rp 600 yang menjadi penerimaan pemerintah pusat dan PBBKB sebesar Rp 300 yang menjadi penerimaan pemerintah daerah, dengan total pajak-pajak yang dipungut sebesar Rp 900 per liter minyak solar. Bila acuan subsidi minyak solar saat ini diberikan paling besar Rp 1.000 per liter dan pajak-pajak yang dipungut sebesar Rp 900 per liter minyak solar, selisih subsidi dengan pajak-pajak adalah Rp 100 per liter minyak solar. Secara umum, bila diperhatikan komponen subsidi dan pajak atas BBM minyak solar saat ini, pengeluaran pemerintah dalam bentuk subsidi "hanya" Rp 100 per liter BBM minyak solar.

Berdasarkan perhitungan subsidi dan pajak-pajak dalam satu liter BBM minyak solar, sesuai perhitungan pemerintah terdapat subsidi harga sebesar Rp 1.000. Akan tetapi, terdapat pula penerimaan negara baik pemerintah pusat melalui PPN dan pemerintah daerah lewat PBBKB yang dipungut dari masyarakat secara total sebesar Rp 900. Dapat diartikan, dalam produk subsidi minyak solar, pemerintah memberikan bantuan subsidi harga sekaligus memungut pajak dari produk minyak solar. Berdasarkan data dari BPH Migas, kuota minyak solar bersubsidi untuk tahun 2015 adalah sebanyak 15,67 juta KL. Dengan asumsi ketentuan fixed subsidy untuk minyak solar sebesar Rp 1.000 per liter, maka subsidi yang dianggarkan dalam APBN 2015 adalah sebesar Rp 15,67 triliun sedangkan pajak yang dipungut untuk PPN Rp 9,402 triliun dan PBBKB sebesar Rp 4,701 triliun. Untuk penerimaan PPN terlihat tidak signifikan dibandingkan dengan implikasi ketidak stabilan harga minyak solar dimasyarakat yang dapat mempengaruhi perekonomian terutama masyarakat yang memang berhak atas subsidi.

Pemungutan pajak memiliki dua fungsi utama, yaitu fungsi budgetair dan fungsi regulerend. Fungsi budgetair adalah fungsi utama pajak atau fungsi fiskal yaitu suatu fungsi dalam mana pajak dipergunakan sebagai alat untuk memasukan dana secara optimal ke kas negara berdasarkan undangundang perpajakan yang berlaku yang berlaku. Fungsi ini disebut fungsi utama karena fungsi inilah yang secara historis pertama kali muncul. Berdasarkan fungsi ini, Pemerintah yang membutuhkan dana untuk membiayai berbagai kepentingan, memungut pajak dari penduduknya. Sedangkan fungsi regulerend atau fungsi mengatur disebut juga fungsi tambahan yaitu suatu fungsi dalam mana pajak dipergunakan oleh Pemerintah sebagai alat untuk mencapai tujuan tertentu. Disebut sebagai fungsi tambahan karena pajak digunakan sebagai pelengkap fungsi utama dan untuk mencapai tujuan terebut pajak digunakan sebagai alat kebijaksanaan.

Bila tujuan pengenaan pajak atas BBM tersebut diatas yang mencapai $15 \%$ dari harga jual eceran adalah untuk revenue productivity atau fungsi budgetair dalam rangka penerimaan negara, maka sangat kecil kemungkinan pemerintah akan memikirkan pengenaaan pajak atas BBM tersebut dapat dijadikan alat sebagai stabilisasi harga BBM bersubsidi, misal: PPN dibebaskan. Sebaliknya bila fungsi regulerend diterapkan, maka perlu dilihat apa yang dituju dari tujuan pemerintah mengenakan pajak atas BBM bersubsidi. Walaupun fungsi regulerend pengenaan pajak atas BBM bersubsidi dapat diharapkan untuk mengatur pola konsumsi BBM bersubsidi dimasyarakat, akan tetapi pemerintah 
mempunyai tugas untuk menyiapkan energi alternatif bagi masyarakat agar memiliki pilihan dalam kebutuhan akan energi sebagai pengganti BBM. Kebijakan konversi minyak tanah ke LPG memang sudah berhasil dilakukan, akan tetapi untuk energi terkait BBM minyak solar ataupun premium hingga saat ini belum ada realisasinya sebagai substitusi dari BBM tersebut.

Yang berlaku saat ini, harga jual eceran jenis BBM diatur sebagai berikut dalam Peraturan Presiden Nomor 191/2014 jo. Permen ESDM 39/2014 adalah sebagai berikut:

1. BBM tertentu:

a. Minyak Tanah ditetapkan berdasarkan penetapan harga nominal;

b. Minyak Solar ditetapkan dengan formula sesuai dengan Harga Dasar ditambah Pajak Pertambahan Nilai (PPN) dan Pajak Bahan Bakar Kendaraan Bermotor (PBBKB), dan dikurangi subsidi paling banyak sebesar Rp 1.000 (seribu rupiah).

2. BBM Khusus Penugasan ditetapkan dengan formula sesuai dengan Harga Dasar ditambah biaya distribusi di wilayah penugasan (2 persen dari harga dasar), ditambah Pajak Pertambahan Nilai (PPN) dan Pajak Bahan Bakar Kendaraan Bermotor (PBBKB).

3. BBM Umum ditetapkan oleh Badan Usaha dengan formula sesuai dengan Harga Dasar ditambah Pajak Pertambahan Nilai (PPN) dan Pajak Bahan Bakar Kendaraan Bermotor (PBBKB), dengan ketentuan sebagai berikut:

a. Harga terendah, dengan margin badan usaha paling rendah lima persen dari harga dasar;

b. Harga tertinggi, dengan margin badan usaha paling tinggi 10 persen dari harga dasar.

Berdasarkan penetapan dalam peraturan diatas, semua jenis BBM baik yang disubsidi maupun tidak disubsidi, dikenakan pajak PPN 10\% dan PBBKB 5\%. Diperlukan penelahaan terkait azas pemungutan pajak, equality, dalam melihat perlakuan pajak atas BBM baik yang bersubsidi maupun tidak diberikan subsidi. Mengutip Suandy (2000) terkait equality, pembebanan pajak diantara subjek pajak hendaknya seimbang dengan kemampuannya yaitu seimbang dengan penghasilan yang dinikmatinya dibawah perlindungan Pemerintah. Dalam hal equality ini tidak boleh suatu negara mengadakan diskriminasi diantara sesama wajib pajak. Dalam keadaan yang sama wajib pajak harus diperlakukan sama dan dalam keadaan berbeda wajib pajak harus diperlakukan berbeda.

Mengenai prinsip equality, Brown \& Jackson (1986) menyatakan bahwa: "taxes are supposed to be 'fair'. It is possible to identify two separate concepts of fairness: horizontal equity and vertical equity. Horizontal equity means that people with equivalent circumstances should be treated fairly, while vertical equity is concerned with fairness between people with differing circumstances". Perbedaan perlakuan pajak terhadap golongan dalam masyarakat diperlukan sebagai bagian dari pemerataan kesejahteraan. Akan sangat tidak adil bila pengenaan pajak disama ratakan terhadap semua lapisan masyarakat.

Terkait fairness dalam suatu sistem perpajakan Devereux (1995) berpendapat:"but designing a tax system which is fair requires looking at all taxes not just one. Some taxes are progressive, some more regressive. More over, fairness also requires us to look at what governments do with tax revenue”. Untuk melihat fairness dalam suatu sistem pajak, perlu dicermati apa yang dilakukan pemerintah dengan penerimaan pajak tersebut untuk keperluan spending pemerintah.

Secara jelas BBM bersubsidi ditujukan bagi masyarakat miskin, walaupun mungkin dalam pelaksanaannya terjadi penyimpangan dalam penyaluran BBM bersubsidi. Perbedaan perlakuan pajak sudah seharusnya dapat dinikmati oleh masyarakat miskin yang menerima subsidi untuk BBM bila pemerintah memperhatikan prisnsip pemungutan pajak equality. Dalam kasus BBM, tidak ada perbedaan perlakuan kebijakan perpajakan terkait PPN dan PBBKB untuk masyarakat miskin yang seharusnya menerima BBM bersubsidi dengan masyarakat lain yang mengkonsumsi BBM nonsubsidi.

Untuk masalah subsidi energi, perlakuan perbedaan pajak terlihat dalam distribusi LPG. Untuk LPG tabung gas $3 \mathrm{~kg}$ yang diberikan subsidi oleh pemerintah, perlakuan PPN adalah ditanggung pemerintah dengan arti PPN tidak membebani nilai jual dimasyarakat. Hal tersebut sesuai dengan Peraturan Menteri Keuangan Nomor PMK-215/PMK.03/2010, Pajak Pertambahan Nilai yang terutang atas subsidi Jenis BBM Tertentu dan LPG Tabung $3 \mathrm{Kg}$ yang dibayarkan kepada Pengusaha ditanggung oleh Pemerintah.

Kebijakan pengenaan pajak atas BBM bersubsidi dengan total tarif $15 \%$ memang mempengaruhi netralitas pajak terhadap BBM bersubsidi dimasyarakat. Disamping itu, produk BBM 
bersubsidi sangat mempengaruhi perekonomian masyarakat. Belum ada kebijakan alternatif pemerintah dalam hal energi baru dan terbarukan hingga saat ini, terutama sebagai pengganti minyak solar. Sehingga masyarakat memang mau tidak mau harus menggunakan BBM bersubsidi. Permasalahan ketidak-tepatan atau penyimpangan dalam penyaluran subsidi BBM, adalah permasalahan diluar kebijakan harga BBM bersubsidi. Dalam pelaksanaannya memang dibutuhkan pengawasan dalam penyaluran BBM bersubsidi. Akan tetapi, jangan sampai dikarenakan alasan permasalahan penyaluran BBM bersubsidi, pemerintah mengabaikan keadilan bagi masyarakat yang memang selayaknya mendapatkan subsidi BBM tersebut. Peranan kebijakan pajak atas BBM bersubsidi dapat dikaji sebagai langkah menstabilkan harga jual eceran dimasyarakat, sehingga perekonomian dapat lebih stabil terutama terkait multiplier effect dari kenaikan harga BBM bersubsidi terhadap kenaikan harga barang dan jasa.

Dalam pengenaan pajak atas BBM bersubsidi minyak solar, produk tersebut dikenakan pajak PPN dan PBBKB dan sudah termasuk dalam harga jual eceran yang ditetapkan pemerintah sebagaimana diatur dalam Peraturan Presiden Nomor 191/2014 jo. Permen ESDM 39/2014: Minyak Solar ditetapkan dengan formula sesuai dengan Harga Dasar ditambah Pajak Pertambahan Nilai (PPN) dan Pajak Bahan Bakar Kendaraan Bermotor (PBBKB), dan dikurangi subsidi paling banyak sebesar Rp 1.000 (seribu rupiah). PPN dikenakan 10\% dan merupakan bagian dari penerimaan pemerintah pusat. Sedangkan PBBKB dikenakan 5\% dan merupakan bagian penerimaan pemerintah daerah. Secara konsep, pengenaan PPN oleh pemerintah pusat dan PBBKB oleh pemerintah daerah terhadap produk BBM, merupakan pajak berganda ekonomis (economic double taxation).

Dari segi peraturan perundang-undangan, terlihat perbedaan perlakuan terkait makanan dan minuman tersebut diatas dikarenakan sudah dikenakan pajak daerah yaitu pajak restoran dan atas tidak dijadikan objek PPN atau bukan barang kena pajak (BKP) untuk menghindari pengenaan pajak berganda. Sedangkan BBM, sudah sangat jelas dikenakan PPN dan PBBKB sebagai pajak daerah. Seharusnya, pembuat kebijakan dalam hal ini pemerintah konsisten dalam menerapkan konsep pajak berganda terhadap produk-produk atau barang-barang yang berpotensi untuk dikenakan pajak secara bersamaan antara pemerintah pusat dan pemerintah daerah. Apabila pajak berganda diterapkan dalam rangka mengurangi efek eksternalitas negatif dari suatu produk, seperti rokok yang dikenakan PPN, cukai (pemerintah pusat) dan Pajak Rokok (pemerintah daerah), hal tersebut dapat mengacu pada fungsi pajak sebagai fungi regulerend untuk mengatur perilaku masyarakat agar terhindar dari resiko negatif dari mengkonsumsi rokok. Akan tetapi, untuk BBM bersubsidi yang memiliki efek luas terhadap perekonomian masyarakat, perlu dibuat kebijakan yang tidak mengenakan pajak berganda untuk menstabilkan harga BBM bersubsidi.

Selain itu, pengenaan pajak secara bersamaan, yaitu PPN 10\% dan PBBKB 5\% terhadap BBM terutama BBM bersubsidi, secara langsung membuat harga jual eceran BBM bersubsidi menjadi lebih mahal. Ditambah lagi karakteristik harga jual eceran BBM bersubsidi yang fluktuatif dan memiliki efek perekonomian masyarakat luas seperti inflasi. Apabila pemerintah ingin membatasi penggunaan BBM termasuk mengurangi subsidi BBM dengan mengenakan pajak yang tinggi, saat ini bukan waktu yang tepat. Negara-negara lain memang mengenakan pajak yang tinggi terhadap BBM. Sebagai contoh harga RON 91 di Thailand per 30 Maret THB 34,46 (THB 15,8144 dalam bentuk pajak, Oil Fund, Conservation Fund), sehingga harga di luar pajak dan pungutan lain adalah THB 18,6456. Di India, sekitar separuh dari harga eceran adalah komponen pajak. Akan tetapi, kebijakan untuk pembatasan penggunaan BBM, juga harus diseinergikan dengan kebijakan terkait lainnya, misal infrastruktur transportasi, terutama transportasi publik. Sehingga masyarakat nyaman dengan fasilitas transportasi publik tersebut dan mengurangi penggunaan kendaraan pribadi.

Mengingat BBM bersubsidi sangat vital bagi perekonomian masyarakat Indonesia, pemerintah perlu mengkaji kebijakan pengenaan pajak atas BBM bersubsidi. Khusus minyak solar, yang merupakan penggerak roda perekonomian masyarakat kecil, seperti untuk transportasi, nelayan atau usaha UMKM, perlu diberikan kelonggaran dari sisi perpajakan, apalagi pajak atas BBM bersubsidi minyak solar terdiri dari 2 jenis pajak, PPN 10\% dan PBBKB 5\%. Pemerintah perlu membuat kebijakan yang pro ekonomi kerakyatan sesuai amanat konstitusi, Pasal 33 Undang-Undang Dasar Negara Republik Indonesia Tahun 1945 untuk dikuasai negara dan dipergunakan untuk sebesarbesarnya kemakmuran rakyat. 
Dalam pengenaan pajak atas BBM bersubsidi minyak solar, alternatif yang dapat ditempuh pemerintah adalah terkait fasilitas pembebasan untuk PPN. Sedangkan untuk PBBKB, merupakan bagian penerimaan daerah guna memperkuat otonomi daerah akan sulit untuk diubah. Kebijakan PPN atas BBM bersubsidi harus sesuai dengan konsep teori PPN dan sesuai dengan Undang-Undang yang berlaku. Terlepas dari kontroversi subsidi BBM dalam pelaksanaannya, kebijakan untuk memberikan fasilitas bebas PPN bagi BBM bersubsidi akan berdampak langsung bagi masyarakat miskin yang memang berhak atas subsidi BBM tersebut. Disamping itu, dengan fasilitas bebas PPN bagi BBM bersubsidi diharapkan dapat meminimalisir dampak dari fluktuasi harga BBM bersubsidi bagi perekonomian masyarakat, seperti kenaikan harga bahan pokok, biaya transportasi hingga dampak inflasi disamping dampak sosial dimasyarakat.

\section{KESIMPULAN DAN SARAN}

\section{Kesimpulan}

1. Kebijakan pemerintah untuk mengenakan pajak atas BBM bersubsidi minyak solar dikarenakan pemerintah tetap menjadikan bagian dari penerimaan bagi negara untuk PPN dan penerimaan daerah untuk PBBKB (revenue productivity). Selain itu, kebijakan pengenaan pajak tersebut merupakan upaya pembatasan konsumsi BBM bersubsidi dimasyarakat yang selalu mengalami over quota setiap tahunnya akibat pemborosan dan juga tidak membebani keuangan negara terkait subsidi BBM dalam APBN. Pembenahan pola subsidi BBM dilakukan melalui bantuan langsung kepada masyarakat yang memang berhak mendapatkan bantuan subsidi tersebut.

2. Alternatif kebijakan dalam pengenaan pajak atas BBM bersubsidi minyak solar adalah dengan memberlakukan pembebasan pajak seperti pembebasan PPN terhadap BBM bersubsidi minyak solar. Hal ini dapat dilakukan agar harga jual eceran BBM bersubsidi minyak solar dapat lebih stabil dikarenakan pengenaan PPN tersebut menambah harga jual eceran dimasyarakat.

\section{Saran}

1. Kebijakan pajak sebagai salah satu instrument kebijakan fiskal dapat dijadikan salah satu kebijakan pemerintah dalam kebijakan harga BBM bersubsidi minyak solar. Pengenaan pajak berupa PPN yang menjadi domain pemerintah pusat dan PBBKB yang dipungut pemerintah daerah telah memenuhi unsur pajak berganda yang menimbulkan distorsi bagi perekonomian mengingat sensitivitas harga BBM bersubsidi yang menimbulkan dampak bagi perekonomian masyarakat. Hal ini dibutuhkan mengingat BBM bersubsidi terutama minyak solar merupakan salah satu produk vital bagi perekonomian masyarakat, selama pemerintah belum mengembangkan energi baru dan terbarukan sebagai konversi penggunaan BBM terutama minyak solar.

2. Pemerintah perlu membuat suatu kebijakan yang tegas terkait pembatasan penggunaan BBM bersubsidi minyak solar hanya dikhususkan bagi masyarakat yang berhak menerima subsidi dan juga sektor-setor perekonomian masyarakat yang memerlukan BBM bersubsidi minyak solar seperti transportasi massal, UMKM atau nelayan. Dengan ketepatan pemberian subsidi BBM khususnya minyak solar, pemerintah dapat melakukan evaluasi atas kebijakan atas pengenaan pajak atas BBM bersubsidi dengan memberikan pembebasan pajak, seperti yang dilakukan pemerintah dalam memberikan pembebasan PPN bagi elpiji tabung $3 \mathrm{~kg}$.

\section{DAFTAR REFERENSI}

Abimanyu, Anggito \& Megantara, Andie (Ed.). (2009). Kebijakan Fiskal: Pemikiran, Konsep, Dan Implementasi. Jakarta: Kompas.

Anderson, James E. (2011). Public Policymaking: An Introduction (Seventh Edition). Boston: Wadsworth.

Brown C.V. and Jackson P.M. (1986). Public Sector Economics (Third Edition). Oxford: Basil Blackwell. 
Dunn, William N. (2000). Pengantar Analisis Kebijakan Publik-Edisi Kedua (Cetakan Ketiga) (Samodra Wibawa, dkk, Penerjemah). Yogyakarta: Gajah Mada University Press.

Devereux, Michael P. (Ed.) (1996). The Economics of Tax Policy. New York. Oxford University Press.

Mansury, R. (1999). Kebijakan Fiskal. Tangerang: YP 4.

Priyatno, Agus. \& Ginting, Rela. (2014). "Puasa” Subsidi BBM Oleh: Susilo Siswoutomo. Jakarta: PT Zanubah Mandiri.

Stiglitz, Joseph E. (1999). Economics Of The Public Sector (Third Edition). New York: W.W. Norton \& Company.

Suharto, Edi. (2005). Analisis Kebijakan Publik: Panduan Praktis Mengkaji Masalah Dan Kebijakan Sosial. Bandung: Alfabeta.

Tambunan, Tulus T.H. (2015). Perekonomian Indonesia: Era Orde Lama Hingga Jokowi. Bogor: Ghalia Indonesia.

Alisjahbana, Armida S. (2012). Kontroversi Kebijakan Kenaikan Harga BBM. Jurnal Kebijakan Ekonomi Volume I No. 1, Agustus 2005 Hal. 1-13.

International Institute For Sustainable Development. Tinjauan Subsidi Energi Di Indonesia. Edisi 1, Volume 1. Maret 2014. www.iisd.org/gsi.

Pusat Data dan Informasi Energi dan Sumber Daya Mineral - Kementrian Energi dan Sumber Daya Mineral (2012). Kajian Supply Demand Energy. www.esdm.go.id.

Tim Reformasi Tata Kelola Migas (2015). Rekomendasi Akhir: Memperkokoh Kelembagaan Sektor Migas Indonesia. http://faisalbasri01.wordpress.com. 